\title{
Evaluating Management Support to the Internal Audit System in Bo District Council, Sierra Leone
}

\author{
Sualiho Sheriff \\ Department of Accounting, School of Social Sciences and Law, Njala University, Bo Campus, Bo, Sierra Leone \\ Email: sualihos@yahoo.com
}

How to cite this paper: Sheriff, S. (2021). Evaluating Management Support to the Internal Audit System in Bo District Council, Sierra Leone. Open Journal of Business and Management, 9, 1603-1618.

https://doi.org/10.4236/ojbm.2021.94087

Received: May 5, 2021

Accepted: July 5, 2021

Published: July 8, 2021

Copyright (๑) 2021 by author(s) and Scientific Research Publishing Inc. This work is licensed under the Creative Commons Attribution International License (CC BY 4.0).

http://creativecommons.org/licenses/by/4.0/

\section{(c) (i) Open Access}

\begin{abstract}
One of the daunting challenges facing the effective operations of Local Councils in Sierra Leone, particularly the Bo District Council is the quality of support services that drive accountability in the use of scarce financial resources. It is on this note that the study is intended to assess management supports towards the internal audit system. The study was conducted in Bo District Council located in the Southern Region of Sierra Leone. Bo District Council consists of 16 Chiefdoms, 25 Councilors, 3 Paramount Chiefs, 25 Wards, 16 Committees, 11 Constituencies, and 13 Core Staff Members. The secondary objectives were: 1) to assess the level of respondents' perceptions on management support to the internal audit system;2) to identify the scale of management support to the internal audit effectiveness, and 3) to establish the relationship between management support and internal audit effectiveness. The instruments employed for data collection include: questionnaires and documentary analysis. The sample population of the study is thirteen (13) core staff members that represents the sample size of the study, and includes all the departments and units of the Bo District Council. The 13 core staff members were selected by stratified sampling selection technique. The study employed descriptive design and results discussed in qualitative and quantitative methods. The reliability test was conducted 0.765 using the Crumb Alpha Test and was considered valid. The key findings of the study include: Lack of full support to the audit committee; lack of independence of the internal audit system; insufficient allocation of budget. It is recommended that the Local Service Commission should let the internal audit system being independent by creating a directorate of the internal audit department.
\end{abstract}

\section{Keywords}

Internal Audit Systems, Effectiveness, Management Supports, Local Council 


\section{Introduction}

Sierra Leone as one of the least under-developed nations is struggling with economic crises and the reforms of the internal audit systems since the civil war broke out in 1991; public institutions across the country have achieved little or no results over the years and the country has experienced deep financial crises in (2014) following the Ebola epidemic and collapse in the global prices of iron ore, rampant corruption, financial irregularities, mismanagement and embezzlement of public funds, political influences for which the Local Councils are no exceptions. All these unbearable issues are evident in the Governance Transition Team Report (2018) and Audit Service Reports of Sierra Leone (2019). The audit system in Sierra Leone lacks internal consistency that is influenced and hindered hugely on management interferences. It is part of the management structure but also lacks full support from top management to enhance its effectiveness. Dellai et al. (2016) mentioned that management has the role of supporting the internal audit system through internal control systems, risk management, and effective governance. Cooper \& Scindler (2013) described that internal audit involves routine checks and balances that determine the success or failure of non-profit-making entities.

The Local Councils in Sierra Leone should comply with the Public Financial Management Act (2016) and Public Financial Management Regulations (2018). It is one of the key responsibilities of the internal audit system to ensure that adherence to these prudent fiscal structures is maintained for effectiveness and compel employees and management of the councils to do the same. Tkachenko (2020) highlighted that the successful implementation of the Public Financial Management reform requires an efficient institution's framework that encompasses legislation, process, and supportive institutional organizational culture. Audit Service Reports (2019) revealed that the Local Councils are still not in compliance with the Public Procurement Act (2016) and Public Procurement Regulations (2018). These frameworks provide the necessary basis for which public finances are well utilized. Audit Service Reports (2019) identified procurement and cash irregularities for all councils across the country.

These include: no procurement plans and documents not approved by the authority, irregularities in the bidding process, contractual terms not fully met, unsupported documents, unapproved expenses, non-payment of statutory obligations, and payroll irregularities. The internal audit system at the Local Councils is neither effective nor independent that helps minimize these pervasive and chronic issues. Zakari (2012) took an impartial standing on the notion that the effectiveness of the internal audit system depends on the level of independence of the internal audit system, and also cited that the extent of added value the internal audit can bring to the organization depends on how effective it is managed in the organization. Mihret \& Woldeyohanes (2008) argued that effectiveness is a more important aspect than efficiency because if the internal audit is not effective, it is worthless regardless of how efficient the audit is. The internal 
audit system is highly influenced by the council's administration since all the powers of the internal auditors are subsumed under the direct supervision of the Chief Administrators.

The directorate of the internal audit system should be created and enacted in the Local Government Act (2004). The study will help the Local Government or Local Service Commission and management of the Bo District Council to develop, review and monitor policies enhancing the effectiveness of the internal audit system.

\section{Related Work}

\subsection{Review of Related Work}

The study reviews different related work regarding the scale of management supports to the internal audit systems:

According to Dellai et al. (2016), without management supports internal audit system is ineffectual, an internal audit on its own does not have the resources to fulfill its work and cannot outsource proficient internal audit staff without management supports. Previous studies have not addressed the scale of supports needed to enhance the internal audit effectiveness even though, Dellai et al. (2016), also pointed out that management systems, sound internal control systems, and effective governance enhance the internal audit effectiveness. The study is also in line with Arena \& Sarens (2015) suggests that the degree of internal audit effectiveness tends to vary with country and organization-level dynamics in an internal audit milieu. (Mihret and Woldeyohanes, 2008) one approach to assessing internal audit effectiveness could be by examining the extent to which the function meets its raison d'être, which is assisting organizations to meet objectives.

Hanefah and Endaya (2013) found that management support has a moderate effect on the internal audit effectiveness. This is due to the data collected that internal audit effectiveness and management support are contingent upon other variables not just between internal audit and management. D'Onaza et al. (2015) internal audit effectiveness increases when the internal audit function can assess and improve the risk management through the adoption of systematic and disciplined approach.

D'onaza et al. (2015) further described that the organization's internal control system is significantly and positively associated with the value of management support provided to the internal audit systems. Sarens et al. (2012) further described that to be effective internal audit system must not only possess sound judgment and critical thinking in risk management but must compel others to act appropriately. Lenz and Hahn (2015) argued that modern internal audit systems have adopted a risk based to be more effective but it does not mean that financial reporting related matters are priority hence, risk management as a tool to internal audit effectiveness can be misleading or rather it is now defeating its purpose. Unam et al. (2014), the extent to which internal controls practices affect the internal audit effectiveness is moderate. Arena and Sarens (2015), Rose 
et al. (2013) and van Rensburg \& Coetzee (2016) also discussed the concept of management support and effectiveness. The objective of the internal audit system is to help members of organizations to effectively discharge their responsibilities. Alzeban and Gwillian (2014) suggest that management support the internal audit effectiveness has a positive effect on the effectiveness of the internal audit system.

Ahmad et al. (2009) pointed out that management support is the second most important determinant of the internal audit effectiveness after the sufficiency of staff. Puttick et al. (2007) and Lee et al. (2009) provided enough empirical evidence to show that there is a positive relationship between management support and the effectiveness of the internal audit system. For the internal audit systems to be effective, they must be consistent with the requirements of management supports and must comply with international best practices. Institute of Internal Auditors (2006) described that the principal aim or goal of the internal audit system is to add value to the organization. It will be concluded that many factors of management support have led to the effectiveness of the internal audit systems.

\subsection{Brief Overview of Local Councils in Sierra Leone}

The Local Council shall be the highest political authority in the Locality and shall have legislative and executive powers to be exercised by following the Local Government Act (2004), and any other enactment and shall be responsible generally for promoting the development of the Locality and the welfare of the People. Bo District Council is amongst the 22 Local Councils in Sierra Leone. The Local Councils are divided into two distinct organs: The political wing headed by the Chairman who is elected for five years capable of re-election for a second term and the Administrative wing headed by the Chief Administrators who can be transferred from and within the 22 Local Councils at any time. The Chief Administrator of the Council is directly responsible to the Local Council Administration and not the Chairman of the Council. However, the Chief Administrator advises the Chairman on the day-to-day administration of the Council and the use of public funds for the development of the Council.

\subsection{Internal Audit Systems in Local Councils}

The Institute of Chartered Accountants of Malawi (ICAM, 2014), refers to Local Councils as non-profit making entities which are run, created, owned, managed, and financed by the government through taxpayers' money. Section 84 (1) of the Local Government Act (2004); states that every Local Council shall have an internal audit department and shall prepare a quarterly report and copy the Minister of Local Government. The above section in the Local Government Act (2004) has not been complied with over the years due to lack of independence and management interferences, considering their reporting lines. 


\subsection{Overview of Literature}

Empirically, the link between management support and the effectiveness of the internal audit system has been tested by different researchers all over the world. It is noteworthy, however, that the evidence generated from this study does not translate into a unanimous agreement among academics, researchers, and policymakers. For instance, some authors adduce evidence of management support and effectiveness of the internal audit system. (Dellai et al., 2016; Pappe, 2014; Alzeban and Gwilliams, 2014; van Rensburg \& Coetzee, 2016) among others. On the other hand, few studies found no relationship between management support and the effectiveness of internal audit systems. For instance, (Zakari, 2012; D'onaza et al., 2015: Lenz and Hahn, 2015) among others do not find any relationship between management support and the effectiveness of the internal audit system. Even though research findings vary among countries, few studies have been identified with gaps which this research paper will discuss.

Dellai et al. (2016) argued on the note that without management support internal audit is not effective. Lee et al. (2009) noted that there is a positive relationship between management support and the effectiveness of the internal audit system. Alzeban and Gwilliam (2014) mentioned that management support affects the internal audit system. Renburgs (2016) discussed that there is a positive relationship between management support and the effectiveness of the audit system. Nevertheless, there was no empirical evidence found in evaluating the level of employees' perceptions on management support; identify/categorize the scale of management support to internal audit systems and establish the relationship between management support and the effectiveness of internal audit system. Although other researchers gave an impartial standing on the notion but the above issues were not discussed by the previous authors but it is however noted that those issues shall be discussed at the end of the study.

Section 15 of the Audit Service Act (2014) states that the Auditor-General shall act independently in the exercise of his duties under Section 119 of the Constitution of Sierra Leone (1991) and shall not be subject to the direction or control of any person or authority. Section 16 (1) of the Public Financial Management Act (2016) empowers the General-Auditor to audit the accounts of public institutions including local councils to prepare and submit to parliament and publish audit reports. The above legal clause has enabled the work of the external audit function to be effective which is far beyond the scope of the internal audit systems for public institutions in the country. However, there is no legal instrument in place to protect the internal audit systems for all public instructions and the internal auditors are seen as enemies not a management structure to achieve institutional objectives; and reliance on the internal audit system is always slim and the report is most often ignored because much support is not rendered to the internal audit systems. Hoos et al. (2017) states that the internal audit objectivity is not compromised by the use of internal audit as a manage- 
ment training ground but rather to promote the relationship with the audit committee.

\section{Methodology}

The study employed descriptive research design and data analyzed into qualitative and quantitative methods to assess the scale of management support to the internal audit system in Bo District Council. The study area is Bo District Council, situated in the Southern Province of Sierra Leone. Bo District Council is one among the 22 Local Councils in Sierra Leone with both a District and a City Council. The city council deals with only the main chiefdom which is Kakua. Bo District has 16 chiefdoms, 25 Councilors, 3 Paramount Chiefs, 25 Wards, 16 Committees, 11 Constituencies, and 13 Core Staff Members. Data from the study were derived from two main sources; primary and secondary sources. Primary data were collected through interviews and the administration of questionnaires to the 13 core staff members of Bo Districts Councils, and the secondary data were generated from documentary review/desk analysis. The sample population of the study is thirteen (13) core staff members which represents the sample size of the study. A sample size of more than (50\%) gives results which can be replaced as representing a significant proportion of the population? The study adopted a stratified sampling technique, and the sample population was divided into strata and from each stratum the core staff members were selected which includes all the departments and units of the Bo District Council. Rahi (2017) described the stratified sampling technique as a selection strategy in which each sub-ground called strata is given an equal chance of proportionate representation of each stratum.

The results were also presented using statistical tools such as tables and figures. Also, the Statistical Package for Social Sciences (SPSS) version 26 and Excel were used for data analysis. Taherdoost (2016) further stated that it is essential to select a representative sample using the appropriate sampling technique as well as the required sample size. The validity of the questionnaire was tested in Pujehun District Council that was not part of the case study. The reliability test was conducted using the Crumb Alpha Test and was found to be 0.765 , thus considered valid. To evaluate the consistency of the instruments, the Cronbach's Alpha (a) analysis conducted and the correlation analysis method was used. A four-point Likert (1932) Scale where the lowest scale represents strongly disagreed and the highest represents strongly agreed. Research ethics was considered and COVID-19 was one of the challenging factors due to persistent lockeddowns and restrictions.

\section{Model Specification}

The following model is formulated for this research to test the research hypothesis set earlier. Most of the variables included in the model are extensively used in 
prior audit research (Mihret and Woldeyohanes, 2008; Cohen and Sayag, 2010) except the management perception of internal audit value and the adopted internal audit charter. The reliability and validity of the model were recognized and used in this research is to analyze and interpret the results of the study:

$$
\begin{aligned}
\text { IAS }= & \alpha+\beta_{1} \mathrm{MS}+\beta_{2} \mathrm{DMP}+\beta_{3} \mathrm{MAS}+\beta_{4} \mathrm{MBP}+\beta_{5} \text { MAIAS } \\
& +\beta_{6} \mathrm{MACIAS}+\beta_{7} \mathrm{MBA}+\beta_{8} \mathrm{MAD}+\beta_{9} \mathrm{MAP}+e_{i}
\end{aligned}
$$

where:

IAS $\rightarrow$ Effectiveness of Internal Audit Systems

MS $\rightarrow$ Managements Support,

DMP $\rightarrow$ Developing Management Policies,

MAS $\rightarrow$ Monitoring Internal Audit Systems

MBP $\rightarrow$ Management International Best Practices

MAIAS $\rightarrow$ Managing Assessments of the Internal Audit Systems

MACIAS $\rightarrow$ Managing Audit Committee to Review Internal Audit Systems

MBA $\rightarrow$ Managing Budgeting Allocation

MAD $\rightarrow$ Managing Audit Documentation

MAP $\rightarrow$ Managing Audit Process

$\alpha \rightarrow$ is a constant, represents the effectiveness of the Internal Audit System when every variable is a zero.

$B_{1-9} \rightarrow$ is the coefficient, in which every marginal change in variables supports internal audit effectiveness.

$e_{i} \rightarrow$ the error term.

\section{Results}

The percentages, frequencies, scaling, and rating the relation between management supports and effectiveness of the internal audit system of Bo District Council are shown in the tables below:

The results from Table 1 disclosed that the majority of the respondents agreed that Bo District Council management policy (76.9\%) and monitoring of controls (76.9\%) promote the effectiveness of the internal audit systems. Also, the majority of the respondents of (69.2\%) agreed that Bo District Council management supports audit systems and it is in compliance with international best practices; (69.2\%) agreed that management assessed the internal audit systems, (46.2\%) also agreed that management supports audit committee during audit processes; and the same (46.2\%) opposed to the fact that full support is not rendered to the audit committee during the audit process. About, (61.5\%) of the respondents indicated that budgeting allocation to support the effectiveness of internal audit system is not rendered fully; (61.5\%) of the respondents agreed that management supports internal audit documentation during the internal audit process and the majority of the respondents of (61.5\%) strongly agreed that the internal audit system is reviewed during the audit process. However, (61.5\%) of the respondents also revealed that the work of the internal audit system is not reviewed 
Table 1. Frequencies and percentages of scale of management support of the internal audit system.

\begin{tabular}{|c|c|c|c|c|c|c|c|c|}
\hline \multirow{2}{*}{ Scale of Management Supports } & \multicolumn{2}{|c|}{ Agreed } & \multicolumn{2}{|c|}{$\begin{array}{l}\text { Strongly } \\
\text { Agreed }\end{array}$} & \multicolumn{2}{|c|}{ Disagreed } & \multicolumn{2}{|c|}{$\begin{array}{r}\text { Strongly } \\
\text { Disagreed }\end{array}$} \\
\hline & $\mathbf{F}$ & $\%$ & F & $\%$ & $\mathbf{F}$ & $\%$ & $\mathbf{F}$ & $\%$ \\
\hline Developing Management Policies & 10 & $76.9 \%$ & & & 3 & $23.1 \%$ & & \\
\hline Monitoring of Internal Audit Systems & 10 & $76.9 \%$ & 3 & $23.1 \%$ & & & & \\
\hline $\begin{array}{c}\text { Management of International } \\
\text { Best Practices }\end{array}$ & 9 & $69.2 \%$ & 1 & $7.7 \%$ & 3 & $23.1 \%$ & & \\
\hline $\begin{array}{l}\text { Management Assessments of } \\
\text { Internal Audit System }\end{array}$ & 9 & $69.2 \%$ & 1 & $7.7 \%$ & 3 & $23.1 \%$ & & \\
\hline $\begin{array}{l}\text { Audit Committee on Internal Audit } \\
\text { Systems }\end{array}$ & 6 & $46.2 \%$ & 1 & $7.7 \%$ & 6 & $46.2 \%$ & & \\
\hline Management Allocation of Budget & 4 & $30.8 \%$ & 1 & $7.7 \%$ & 8 & $61.5 \%$ & & \\
\hline $\begin{array}{l}\text { Management Supports } \\
\text { Audit Documentation }\end{array}$ & 8 & $61.5 \%$ & 2 & $15.4 \%$ & 3 & $23.1 \%$ & & \\
\hline Management Supports Audit Process & 8 & $61.5 \%$ & 2 & $15.4 \%$ & 3 & $23.1 \%$ & & \\
\hline $\begin{array}{l}\text { External Audit on Internal } \\
\text { Audit System Reviews }\end{array}$ & 4 & $30.8 \%$ & 1 & $7.7 \%$ & & & 8 & $61.5 \%$ \\
\hline
\end{tabular}

by the external audit function during audit work.

The results from Table 2 depicted that (46.2\%) and (38.5\%) of the respondents rated that developing management policy and monitoring internal audit systems is very effective. Furthermore, (61.5\%) of the respondents rated that complying with best practices and assessing the internal audit system of Bo District Council is not effective to enhance the audit process, while (46.2\%) of the respondents rated audit committee, (53.8\%) of budgeting allocation or resources as partially effective. Only (53.8\%) of the core staff members rated approving audit documentation is partially effective.

This implied that much support in terms of documentation is not rendered during the audit process, and (46.2\%) of the majority of the core staff rated the internal systems to be considered effective and, (76.9\%) rated that reviewing the work of the internal audit system is not effective.

The statistics from Table 3 showed that (53.8\%) of the respondents strongly agreed that there is a strong relationship between management support and internal audit effectiveness, while (38.5\%) of them also agreed. The result implied that there is a positive relationship between management supports and the effectiveness of the internal audit system in Bo District Council.

Level of significance $=0.05$ (1-tailed). IAS = Internal Audit System

Correlation Analysis: The study employed the zero-order correlation to establish the relationship between the variables using the Pearson ( $r$ ) correlation coefficient which measures linear correlation among variables. It depicts the 
magnitude and direction of the relationship as shown below:

Using the rating level of;

0 to $\pm 0.3=$ Weak Relationship

\pm 0.4 to $\pm 0.6=$ Moderate/Average Relationship

\pm 0.7 to \pm 0.9 = Very Strong Relationship.

The results for Table 4 depicted that there is a very strong positive relationship between management support and the effectiveness of internal audit systems at $(r=0.715)$ and at a level of significance (0.05), thus implied that solid management policies enhanced the internal audit effectiveness.

\section{Discussions}

\subsection{Supporting and Developing Management Policy for the Internal Audit Systems}

The study revealed that the majority of respondents agreed to the view that management supports the internal audit system, and few opposed to the fact that

Table 2. Scale of management supports and effectiveness of internal audit system.

\begin{tabular}{|c|c|c|c|c|c|c|c|c|}
\hline \multirow{3}{*}{$\begin{array}{c}\text { Scale of } \\
\text { Management Supports }\end{array}$} & \multicolumn{8}{|c|}{$\begin{array}{l}\text { Scale of Management Support } \\
\text { to the Internal Audit System }\end{array}$} \\
\hline & \multicolumn{2}{|c|}{$\begin{array}{l}\text { Very } \\
\text { Effective }\end{array}$} & \multicolumn{2}{|c|}{ Effective } & \multicolumn{2}{|c|}{$\begin{array}{l}\text { Partially } \\
\text { Effective }\end{array}$} & \multicolumn{2}{|c|}{$\begin{array}{c}\text { Not } \\
\text { Effective }\end{array}$} \\
\hline & & $\%$ & & $\mathrm{~F} \%$ & & F \% & & F \% \\
\hline Developing Management Policies & 6 & $46.2 \%$ & 3 & $23.1 \%$ & 2 & $15.4 \%$ & 2 & $15.4 \%$ \\
\hline Monitoring Internal Audit Systems & 5 & $38.5 \%$ & 5 & $38.5 \%$ & 2 & $15.4 \%$ & 1 & $7.7 \%$ \\
\hline Complying with International Practices & 1 & $7.7 \%$ & 3 & $23.1 \%$ & 1 & $7.7 \%$ & 8 & $61.5 \%$ \\
\hline Assessing Internal Audit Systems & 2 & $15.4 \%$ & 2 & $15.4 \%$ & 1 & $7.7 \%$ & 8 & $61.5 \%$ \\
\hline Supporting Audit Committee & 3 & $23.1 \%$ & 1 & $7.7 \%$ & 6 & $46.2 \%$ & 3 & $23.1 \%$ \\
\hline Budgeting Allocation & 1 & $7.7 \%$ & 2 & $15.4 \%$ & 7 & $53.8 \%$ & 2 & $15.4 \%$ \\
\hline Approving internal audit documents & 1 & $7.7 \%$ & 2 & $15.4 \%$ & 7 & $53.8 \%$ & 2 & $15.4 \%$ \\
\hline Supporting internal audit systems & 2 & $15.4 \%$ & 6 & $46.2 \%$ & 3 & $23.1 \%$ & 2 & $15.4 \%$ \\
\hline Reviewing internal audit activities & 1 & $7.7 \%$ & 1 & $7.7 \%$ & 1 & $7.7 \%$ & 10 & $76.9 \%$ \\
\hline
\end{tabular}

Table 3. Establish the relation between management support and the effectiveness of the internal audit systems.

\begin{tabular}{ccccc}
\hline Response & Frequency & Percent & Valid Percent & Cumulative Percent \\
\hline Strongly Agreed & 7 & 53.8 & 53.8 & 53.8 \\
Agreed & 5 & 38.5 & 38.5 & 92.3 \\
Not Sure & 1 & 7.7 & 7.7 & 100 \\
Disagreed & 0 & 0 & 0.0 & 0.0 \\
Strongly Disagreed & 0 & 0 & 0.0 & 0.0 \\
\hline
\end{tabular}


Table 4. The relation between management support and effectiveness of internal audit.

\begin{tabular}{lccc}
\hline & & Management Support & Effectiveness of IAS \\
\hline & Pearson Correlation & 1.000 & $0.682^{\star}$ \\
Management Support & Sig. (2-tailed) & 0.000 & 13 \\
& $\mathrm{~N}$ & 13 & \\
Effectiveness of IAS & Sig. (2-tailed) & 0.000 & $0.682^{\star}$ \\
\hline
\end{tabular}

full support is not rendered to the internal audit system in Bo District Council. This is due to a lack of independence and reporting-line of the internal audit system; as the powers of the internal auditors are subsumed under the direct supervision of the Chief Administrators. The findings also corroborate with the work of the Chartered Institute of Public Finance and Accountancy (CIPFA, 2003); which points out that independence and objectivity are key elements in the effectiveness of the internal audit systems.

Also, two-thirds majority of the respondents displayed that management internal policies of the council promote the internal audit systems, and one-third of the respondents agreed that management policies do not contribute to the internal audit effectiveness. This is also supported by Badara and Saidin (2014); an effective internal control system can influence the effectiveness of internal audit systems, and monitoring the components of internal control systems do contribute to the effectiveness of the internal audit system.

\subsubsection{Monitoring and Compliance with International Best Practices}

The research paper revealed that two-thirds of the respondents agreed that management monitored and reviewed the internal audit systems and it is in compliance with international best practice, and one-third agreed that the internal audit system is not monitored and complied with international best practices. Alzeban and Gwilliam (2014) state that internal audit independence is of paramount value in providing effective internal audit service to management for it needs an atmosphere of objectivity and uninhibited appraisal and reporting of findings without influence from the units audited. Alzeban and Gwilliam (2014) also found out positive relationship between internal audit effectiveness and management support. This is because management support can equally have a positive impact on internal audit effectiveness. This implied that management support on its own cannot guarantee internal audit effectiveness.

\subsubsection{Reviewing and Assessing the Internal Audit Systems in Bo District Council}

The research paper revealed that reviewing the work of the internal audit system by the external audit function is not spontaneous and the exercise is not rigorous to enhance the effectiveness of the internal audit system. The study also corro- 
borates with the work of Muqattash (2017) and Badara \& Salehi (2014) argued that internal audit activity in an organization should be an independent process. Few respondents have opposite views that the reviewed process of the internal audit system is not done during an audit process. However, two-third of the respondents affirmed that the internal audit system is assessed regularly and one-third opposed the view that an assessment of the system is not perpetual. The study further showed that the audit committee reviewed the internal audit work but much support is not rendered to the audit committee for thorough assessments. The audit committee in practice remains unable to detect whether management exerts pressure on the internal audit systems, thus failing to protect internal audit systems independence, and internal audit should have direct communication with audit committee which stimulates the organizational status. Vasile and Mitran (2015), the existence of an audit committee does not mean the independence or the organization will function effectively.

\subsubsection{Budgeting Allocation and Approving Internal Audit Documentation}

The research paper revealed that a sufficient budgeting allocation is not attached to the internal audit system at Bo District Council. A budgeting allocation is paramount to all local councils in the country, and insufficient allocation of resources will dissuade the internal audit effectiveness and hinder its operational efficiency. Giving a sufficient allocation of budget and other essential services to the audit department will enhance its operational efficiency. The study also discussed that one-third of the respondents affirmed that management supports internal audit documentation and two-third of the majority of the respondents showed that full support in terms of source documents and other essential matters is not rendered during the audit process.

\subsection{Scale of Management Support to Internal Audit System of the District Council}

Scaling of management supports showed that management policies and monitoring of controls are effective to promote the internal audit system. Such policies are not in compliance with international best practices and thorough assessments of the internal audit system. However, scaling management support towards audit committee; support audit documentation, and budgeting allocation is not effective, this implied that much attention is not rendered during the audit period. The internal auditors have the right to be previewed to all internal documentation, sufficient allocation of budget, and renders full support to the audit committee to do their job. Finally, reviewing the work of the internal activities is not effective by external auditors; as such review promotes the effectiveness of the internal audit systems. The study is in line with Mihret and Woldeyohanes (2008) which showed that a positive linkage exists between management support and internal audit effectiveness. 
The authors further indicated the positive and significant relationship of this determinant with all the other variables that impact the effectiveness of the internal audit function. The levels of management support make internal audit function enable organizations to improve internal audit effectiveness. The results also revealed that there was a relationship between management supports and the effectiveness of the internal audit function in Bo District Council. The majority of the respondents indicated that management internal policies rendered to the internal audit promote its effectiveness. The research findings are in line with the contributions of Unam et al. (2014), Badara and Saidin (2014), that management support is one of the factors that leads to the effectiveness of the internal audit work. Alzeban and Gwilliam (2014) also provided that there is a positive correlation between management policies and internal audit effectiveness. Mihret and Woldeyohanes (2008) revealed that the effectiveness of the internal audit largely depends on management policies.

\subsection{The Relation between Management Support and the Effectiveness of Internal Audit}

The results revealed that there was a relationship between management supports and the effectiveness of the internal audit systems in Bo District Council. The majority of the respondents indicated that management internal policies rendered to the internal audit function promote its effectiveness. The research findings are in line with the contributions of Unam et al. (2015), Badara and Saidin (2014) provided that management support is one of the factors that leads to the effectiveness of the internal audit systems. Alzeban and Gwilliam (2014) also provided that there is a positive correlation between management policies and internal audit effectiveness. D'Onaza et al., (2015) showed that an organization's internal control system is significantly and positively associated with the value of management support provided to the internal audit systems.

\section{Limitation and Future Research}

The research paper is no exception to the fact that it is impossible to conduct a research of this nature without limitation. The initial plan for this study was to cover two cities and districts councils but due to the impact of COVID-19 on the nation and other restrictions.

The research was focused on the core staff members of Bo District Council located in the Southern Sierra Leone. Therefore, future study should be focused on the 22 local councils and with different categories of staff members for all the councils across the country.

\section{Conclusion}

\subsection{Management Supports to Internal Audit System}

It could be recommended that Bo District Council management supports the internal audit systems in different ways. The Council develops management pol- 
icies and ensures monitoring and supervision of those policies. Such policies comply with international best practices; adverse to insufficient allocation of budget; approves audit documentation and reviews the internal audit activity. Also, much support is not rendered to the audit committee to be assertive in their functions.

\subsection{Scale of Management Supports to the Internal Audit System}

The ratings of different levels of management supports comprise diverse views or opinions from the respondents in the context of the internal audit systems. Some respondents rated that support is necessary to enhance the effectiveness of the internal audit system, while others opposed that such supports are not sufficient to enhance the effectiveness of the internal audit systems. Therefore, management support is insufficient in terms of budget allocation and audit committee to bring out the effectiveness of the internal audit systems. Therefore, the internal audit system has not spontaneously improved in Bo District Council.

\subsection{Relation between Management Support and the Effectiveness of Internal Audit Systems}

The research paper explicitly conducted that management support and the effectiveness of the internal audit systems have a positive relationship in Bo District Council. Management policies, sufficient budgeting allocation, thorough internal audit assessment, and detailed review of the internal audit systems enhanced internal audit effectiveness. However, management support is not the only factor that affects the effectiveness of the internal audit system.

\section{Recommendations}

The following recommendations would be useful:

1) It is recommended that since most of the core staff affirmed that Bo District Council management gives support to the internal audit system, it is but necessary that the council improves on the support needed so the internal audit department will be equipped enough for effective and efficient operations within the district. The Local Service Commission should establish a directorate of internal audit system for all the district councils as a body through which the internal auditors channel their reports. The directorate also should determine the allocation of budget and other supports to enhance the internal audit effectiveness.

2) The research paper recommends that Bo District Council monitors and evaluates the internal audit works and processes and reviews where necessary, the internal audit department be independent of the general administration of the Council. The Local Government should strengthen the internal policies of the Council with stringent and solid controls that will support the audit committee to be proactive in assessing and developing an assessment schedule during the audit period and that should be devoid from management interferences.

3) The study also recommends that since all the core staff displayed that 
management support is not the only factor that influences the effectiveness and efficiency of the internal audit system. Therefore, the Local Government should devise more strategies for enhancing the efficacy of the internal audit systems and should be in adherence to the international best practices and standards. This can be done by setting solid management policies; enact legal instrument to support internal audit systems; support audit committee to be assertive; sufficient allocation of budget and improve on the conditions of service for internal audit staff. This can enhance their effectiveness and efficiency.

4) The Local Government should design a strategy to retain staff members, improve on conditions of service and consider internal councils' transfers as experienced staff ensures organizational effectiveness and efficiency. The Government should embark on intensive training for core staff members on the internal audit systems, assessment criteria, capacity building, and experience sharing platform for all the councils across the country.

\section{Conflicts of Interest}

The author of this manuscript officially declares no conflicting interest towards the publication of the research paper.

\section{References}

Ahmad, N. H., Othman, R., Othman, R., \& Jusoff, K. (2009). The Effectiveness of Internal Audit in the Malaysian Public Sector. Journal of Modern Accounting and Finance, 5, 53-62.

Alzeban, A., \& Gwilliams, D. (2014). Factor Affecting the Internal Audit Effectiveness: A Survey of the Saudi Public Sector. Journal of International Accounting, Auditing and Taxation, 23, 74-86. https://doi.org/10.1016/j.intaccaudtax.2014.06.001

Arena M., \& Sarens. G. (2015). Editorial: Internal Auditing: Creating stepping Stones for the Future. International Journal of Auditing, 19, 131-133. https://doi.org/10.1111/ijau.12053

Audit Service Act (2014). The Sierra Leone Gazette (Vol. 10 CXXXI, pp. 16).

Audit Service Reports (2019). Sierra Leone Government.

Badara, M. S., \& Saidin, S. Z. (2014). Empirical Evidence of Antecedents of Internal Audit Effectiveness at Local Government Level. Journal of Social Development Sciences, 3, 404-412.

Badara. M. S., \& Saidin, S. Z. (2014). Empirical Evidence of Antecedent of Internal Audit Effectiveness from Nigeria Perspective. Middle East Journal of Scientific Research, 19, 460-471.

Chartered Institute of Public Finance and Accountancy (CIPFA) (2003). Code of Practices for Internal Audit in the Local Government in the United Kingdom, Consultative Draft. London: Chartered Institute of Public Finance and Accountancy.

Cohen, A., \& Sayag, G. (2010). The Effectiveness of Internal Auditing: An Empirical Examination of its Determinants in Israeli Organizations. Australian Accounting Review, 20, 296-307. https://doi.org/10.1111/j.1835-2561.2010.00092.x

Cooper, D., \& Scindler, P. (2013). Business Research Methods (12th ed.). Boston, MA: McGraw-Hill. 
D’Onaza, G., Selim, G. M., Melville. M. G., \& Allegrini, M. (2015). A Study of Internal Perception of the Function to Add Value. International Journal of Audit, 19, 182-194. https://doi.org/10.1111/ijau.12048

Dellai, H., Omri, M.A., \& Omri, B. (2016). Factor Affecting Internal Audit Effectiveness in Tunisian Organizations. Research Journal of Finance and Accounting, 7, 208-221.

Hanefah, M. M., \& Endaya, K. A. (2013). Internal Audit Effectiveness: An Approach Proposition to Develop the Theoretical Framework. Research Journal of Finance and Accounting, 4, 92-102.

Institute Chartered Accountants of Malawi (ICAM) (2014). Public Sector Accounting and Finance Manual. Blantyre: Institute Chartered Accountants of Malawi.

Institute of Internal Auditors (IIA) (2006). The Role of Auditing in Public Sector Governance. Lake Mary, FL: Institute of Internal Auditors.

https://www.theiia.org/download.cfm?file3512

Lee, M., Haron, H. H., Ismail, I., Haat, M. H. C., Zaini, N., Ying, T. S., Lee, L. C., \& Nasar, M. F. (2009). Principles and Contemporary Issues in Internal Auditing (2nd ed.). Kuala Lumpur: McGraw-Hill Malaysia.

Lenz, R., \& Hahn, U. (2015). A Synthesis of Empirical Internal Audit Effectiveness Literature Pointing to New Research Opportunities. Managerial Auditing Journal, 30, 1-42. https://doi.org/10.1108/MAJ-08-2014-1072

Lenz, R., Sarens, G., \& Hoos, F. (2017). Internal Audit Effectiveness: Multiple Research Study Involving Chief Audit Executives and Senior Management. EDPACS, 55, 1-7. https://doi.org/10.1080/07366981.2017.1278980

Likert, R. (1932). A Technique for the Measurement of Attitudes. Archives of Psychology, 22, 1-55.

Local Government Act (2004). The Sierra Leone Government Gazette(Vol. 15).

Mihret, D. G., \& Woldeyohannis, G. Z. (2008). Value-Added Role of Internal Audit: An Ethiopian Case Study. Managerial Auditing Journal, 23, 567-595. https://doi.org/10.1108/02686900810882110

Muqattash, R. S. (2017). Factors Affecting Internal Auditors' Objectivity: Individual-Level Evidence from the United Arab Emirates. Electronic Journal of Applied Statistical Analysis, $10,542-560$.

Public Financial Management Act (2016). The Sierra Leone Gazette (Vol. CXXXXI, p. 34).

Public Financial Management Regulation (2018). The Sierra Leone Gazette (Vol. CXXXIX, p. 19).

Public Procurement Act (2016). The Sierra Leone Gazette (Vol. CXXXVI., pp. 20).

Public Procurement Regulations (2018). The Sierra Leone Gazette (Vol. CXXXIX., p. 17).

Puttick, G., van Esch, S. D., \& Kana, S. P. (2007). Principles and Practice of Auditing (9th ed.). Cape Town: Juta Academic.

Rahi, S. (2017). Research Design and Methods: A Systematic Review of Research Paradigms Sampling issues and Instruments Development. International Journal of Economic and Management Sciences, 6, Article No. 403.

Rose, A. M., Rose. J. M., \& Norman, C. S. (2013) Is the Objectivity of Internal Audit Compromised When IAF Is a Management Training Ground? Accounting \& Finance, 53, 1001-1019. https://doi.org/10.1111/acfi.12025

Salehi, M., Arianpoor, A., \& Salehi, F. (2013). Investigating the Effect of Internal Audit on 
the Performance of Private Banks' System. Journal of Accounting, Business \& Management, 20, 46-58.

Sarens, G., Abdolmohammadi, M. J., \& Lenz, R. (2012). Factors Associated with the Internal Audit Function's Role in Corporate Governance. Journal of Applied Accounting Research, 13, 191-204. https://doi.org/10.1108/09675421211254876

Taherdoost, H. (2016). Sampling Methods in Research Methodology: How to Choose Sampling Techniques for Research. International Journal of Academic Research in Management, 5, 18-27. https://doi.org/10.2139/ssrn.3205035

The Constitution of Sierra Leone (1991). The Sierra Leone Gazette.

The Republic of Sierra Leone, Office of the President (2018). Governance Transition Team Report (pp. 2-5). Freetown: The Republic of Sierra Leone, Office of the President.

Tkachenko, L. (2020). Public Finance Challenges and Opportunities, Anthens of Journal of Business and Economics. Anthens Institute for Education and Research, 6, 73-98. https://doi.org/10.30958/ajbe.6-1-4

Unam, M. J., Inneh, G. E., \& Ojo, O. V. (2014). Internal Controls and Operating Performance of Small Business in Logos Metopopolis. International Conference on Accounting, Finance and Management, Ile-Ife, 9-11 July 2014, 237-256.

van Rensburg, J. O. J., \& Coetzee, P. (2016). Internal Audit Public Sector Capability. Journal of Public Affairs, 16, 181-191. https://doi.org/10.1002/pa.1574

Vasile, E., \& Mitran, D. (2015). The Relationship between Audit Committee and Decision Makers within an Organization. Audit Financials, 16, 518-525. https://doi.org/10.20869/AUDITF/2016/137/518

Zakari, C. J. (2012). Basic Research Methods for Librarians. Los Angeles: California Press. 